\title{
Masalah Psikososial pada Remaja di Sekolah Asrama di Kota \\ Lhokseumawe, Provinsi Aceh
}

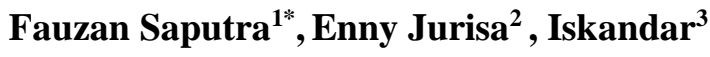 \\ 1.2.3 STIKes Bumi Persada Lhokseumawe
}

Koresponden*:

Fauzan Saputra : STIKes Bumi Persada Lhokseumawe

Email : saputrafauzan66@gmail.com

\begin{abstract}
Abstrak
Remaja yang melanjutkan pendidikan pada sekolah yang memiliki asrama berisiko mengalami masalah psikososial yang lebih tinggi dibandingkan remaja yang tidak tinggal di asrama. Tujuan penelitian ini yaitu untuk mengidentifikasi masalah-masalah psikososial yang dialami oleh remaja yang tinggal di asrama. Penelitian ini menggunakan pendekatan descriptive quantitative dengan jumlah sampel sebanyak 106 siswa yang didapatkan dengan metode simple random sampling. Kuesioner yang digunakan yaitu Strenghts and Difficulties Questionaire (SDQ) versi bahasa Indonesia. Hasil penelitian menunjukkan 30\% remaja yang tinggal di asrama mengalami masalah psikososial, remaja laki-laki cenderung lebih banyak mengalami masalah psikososial (58\%) seperti masalah teman sebaya (29\%) dan masalah perilaku (15\%), sedangkan remaja perempuan cenderung memiliki masalah emosional (14\%). Disarankan agar pihak sekolah berkerja sama dengan Dinas Kesehatan dan puskesmas untuk melakukan deteksi dini masalah psikososial dan memberikan intervensi awal untuk menurunkan risiko dan dampak masalah psikososial remaja di masa yang akan datang.
\end{abstract}

Kata kunci: Asrama, sekolah, masalah, psikososial, remaja

\begin{abstract}
Adolescents who continue their education at boarding schools experience higher psychosocial problems compared to adolescents at schools without dormitory. The study aimed to investigate psychosocial problems of adolescents at boarding school. This study applied quantitative descriptive with a total sample of 106 students obtained by the simple random sampling method. The questionnaire used the Indonesian version of Strengths and Difficulties Questionnaire (SDQ). The results showed $30 \%$ of adolescents at boarding school experienced psychosocial problems; male adolescents tended to have psychosocial problems (58\%) such as peer problems (29\%) and conduct problems (15\%), while female adolescents had risk for emotional problems (14\%). The school was suggested to collaborate with the Public Health office and Public Health Center to perform psychosocial problems sreening and provide early interventions to decline the risk of psychosocial problems and minimize the impact of the problems in the future.
\end{abstract}

Keywords: boarding, school, problems, psychosocial, adolescents

\section{PENDAHULUAN}

Pada setiap tahap kehidupan, manusia mempunyai tugas tumbuh kembang sesuai usia, dimana tugas tersebut harus dipenuhi agar manusia dapat melaksanakan fungsinya secara utuh. Menurut Badan Pusat Statistik (BPS), jumlah populasi penduduk usia 
10-18 tahun yaitu 64,19 juta jiwa atau $24,01 \%$ remaja hampir mengisi seperempat jumlah penduduk di Indonesia (BPS, 2019). Sebagai salah satu kelompok dengan jumlah populasi terbanyak, remaja memiliki tugas tumbuh kembang yang cukup kompleks, hal ini dipengaruhi oleh perubahan hormonal yang sedang terjadi. Menurut Keliat dan Akemat (2015), remaja harus mengembangkan kemampuan psikososial berupa pencapaian identitas diri sehingga dapat menemukan ciri khas mereka masing-masing dan mencegah terjadinya kebingungan peran yang akan berdampak pada gangguan konsep diri.

Selanjutnya, Keliat dkk (2020) menyampaikan bahwa remaja dengan perkembangan psikososial yang sehat menunjukkan kemampuan penilaian diri secara objektif, memiliki sahabat, mempunyai ketertarikan terhadap lawan jenis, mengembangkan bakat yang disukai, memiliki cita-cita, dan mempunyai prestasi akademik. Bila remaja tidak mampu menunjukkan kemampuan-kemampuan di atas, berarti remaja mengalami masalah psikososial berupa kebingungan peran. Dampak dari kebingungan peran ini dapat menyebabkan beberapa masalah kejiwaan seperti kecemasan dan depresi, sehingga remaja tersebut cenderung melakukan perilaku-perilaku yang berisiko seperti melakukan kekerasan, merokok, minum alkohol atau menggunakan Napza, sehingga pada akhirnya memiliki risiko tinggi bunuh diri (Hallfors, Waller, Ford \& Halpern, 2004; Galaif, Sussman, Newcomb \& Locke, 2011; Consoli, Peyre, Speranza et al, 2013).

Hasil skrining yang dilakukan oleh Direktorat P2MKJN (Pencegahan dan Pengendalian Masalah Kesehatan Jiwa dan NAPZA) Kemenkes RI dan Pengurus Pusat Perhimpunan Dokter Spesialis Kedokteran Jiwa Indonesia (PP PDSKJI) pada 1300 siswa SMA di Jakarta Selatan menunjukkan bahwa $30 \%$ siswa berisiko mengalami depresi, sedangkan $10 \%$ lainnya memiliki gangguan emosional (Sukmasari, 2016). Hasil tersebut cukup mengejutkan, apalagi sampel pada skrining tersebut di lakukan pada kota besar yang memiliki fasilitas, sumber informasi dan sumber daya manusia yang lebih baik dari wilayah lain. Selain itu, perkembangan psikososial pada remaja di sekolah berasrama juga perlu mendapatkan perhatian, apalagi beberapa penelitian menyimpulkan bahwa siswa SMA yang tinggal di asrama lebih berisiko mengalami masalah psikososial dibandingkan teman-temannya yang tidak tinggal di asrama. 
Martin, Papworth, Ginns \& dilakukan pada 210 remaja di salah Liem (2014) menyampaikan bahwa satu SMA di Cisarua menunjukkan kemampuan akademik, kehadiran di bahwa 71,7\% remaja yang tinggal di kelas, motivasi, kegiatan asrama mengalami kecemasan, dan ekstrakulikuler, dan kedisiplinan sebagain besar siswa mengalami remaja yang tinggal di asrama memang kecemasan sedang (31,9\%), sedangkan lebih baik dibandingkan remaja yang $15,9 \%$ siswa mengalami depresi. tidak tinggal di asrama, hal ini terjadi Penelitian ini menyimpulkan bahwa, karena kehidupan belajar dan untuk situasi Indonesia, remaja yang sosialisasi remaja dapat terpantau menempuh pendidikan pada sekolah dengan baik. Tetapi, tingginya berasrama berisiko mengalami intensitas interaksi remaja dengan masalah-masalah psikososial seperti teman sekolahnya ternyata juga dapat masalah emosional, masalah dengan memberikan dampak yang kurang teman sebaya, masalah perilaku menguntungkan. Salah satu penelitian negatif, dan hiperaktif. Tetapi pada remaja Eskimo menunjukkan penelitian sejenis masih sedikit bahwa 49\% siswa baru mengalami dilakukan di Provinsi Aceh, Khususnya masalah sosial dan emosional, Kota Lhokseumawe, sebagai salah satu sedangkan $25 \%$ diantaranya dilaporkan wilayah di Indonesia yang mengalami masalah yang lebih serius memberlakukan Syariah Islam, (Kleinfeld \& Bloom, 1977). Remaja sehingga penelitian ini perlu dilakukan yang tinggal di asrama memang kerap untuk mendapatkan gambaran masalah mengalami masalah sosial seperti psikososial pada remaja yang tinggal di bullying dan kecenderungan pilih-pilih teman, sehingga remaja yang kurang populer dan inferior cenderung menyendiri dan berisiko mengalami depresi (Mander \& Lester, 2017).

Penelitian yang dilakukan oleh Fathonah, Herawaty \& Fitria (2017) pada sekolah berasrama di Provinsi Jawa Barat mendukung penelitianpenelitian di atas. Penelitian yang asrama berbasis Islam yang berbeda dengan sekolah asrama lain di Indonesia.

\section{METODE}

Penelitian dilakukan dengan pendekatan deskriptif kuantitatif. Penelitian ini bertujuan untuk mengetahui gambaran masalah psikososial yang terjadi pada remaja SMA yang tinggal di asrama, antara 
lain masalah emosional, masalah teman sebaya, hiperaktivitas, dan masalah perilaku. Penelitian ini dilakukan pada April 2019 pada salah satu SMA swasta di Kota Lhokseumawe dengan jumlah sampel sebanyak 106 siswa, yang didapatkan melalui teknik simple random sampling. Untuk mendapatkan masalah psikososial pada remaja, peneliti menggunakan kuesioner Strenghts and Difficulties Questionnaire (SDQ) versi Indonesia yang diterjemahkan oleh Wiguna dam Hestyanti (Goodman, 2014) dan menunjukkan angka reliabilitas yang baik yaitu $\alpha=.773$ sehingga dapat digunakan untuk populasi Indonesia (Oktaviana \& Wimbarti, 2014).

SDQ terdiri dari 25 soal yang terdiri dari lima dimensi, yaitu dimensi emosional (5 soal), dimensi perilaku (5 soal), dimensi hiperaktivitas (5 soal), dimensi masalah teman sebaya (5 soal), dan dimensi perilaku prososial (5 soal). Pilihan jawaban yang tersedia yaitu “Tidak Benar" (skor 0), "Agak Benar" (skor 1), dan "Benar" (skor 2). Total skor kesulitan yaitu 40, dengan kategori antara lain: skor 15-17 agak tinggi, 18-19 tinggi, dan 20-40 sangat tinggi. Sedangkan skor masalah psikososial antara lain; masalah emosional (skor 5-10), masalah perilaku (skor 4-10) masalah hiperaktivitas (skor 6-10), dan masalah teman sebaya (skor 3-10) (Verhulst \& Ende, 2006).

Proses pengumpulan data dilakukan setelah peneliti mendapatkan izin dari kepala sekolah. Seluruh siswa yang terpilih dikumpulkan pada aula, kemudian peneliti menjelaskan tentang penelitian yang akan dilakukan dan terkait kuesioner yang digunakan. Setelah siswa mengerti tentang tujuan penelitian dan cara mengisi kuesioner SDQ, maka setiap siswa menandatangani format persetujuan menjadi responden penelitian. Kemudian, setiap siswa diminta untuk mengisi semua pertanyaan yang tersedia dan siswa memilih jawaban yang paling tepat menggambarkan perasaannya. Proses pengumpulan data membutuhkan waktu selama 20-30 menit, kemudian siswa mengumpulkan lembar jawaban dan peneliti melakukan pengecekan kelengkapan jawaban siswa dan melakukan analisis.

\section{HASIL}

Penelitian ini bertujuan untuk mengetahui gambaran masalah psikososial pada remaja SMA yang melanjutkan pendidikan pada sekolah berasrama, dengan fokus pada dimensi emosional, masalah perilaku, 
hiperaktivitas, dan masalah teman sebaya. Hasil penelitian dapat dilihat pada tabel-tabel berikut.

Tabel 1. Perbandingan Jenis Kelamin Siswa SMA dengan masalah psikososial di asrama sekolah Kota Lhokseumawe tahun 2019 ( $n=106)$

\begin{tabular}{|c|c|c|c|c|c|c|}
\hline \multirow{3}{*}{$\begin{array}{c}\text { Jenis } \\
\text { Kelamin }\end{array}$} & \multicolumn{6}{|c|}{ Interpretasi SDQ } \\
\hline & \multirow{2}{*}{$\begin{array}{c}\text { Normal } \\
(\%)\end{array}$} & \multicolumn{4}{|c|}{ Abnormal (\%) } & \multirow{2}{*}{$\begin{array}{c}\text { Total } \\
(\%)\end{array}$} \\
\hline & & Sedikit tinggi & Tinggi & Sangat Tinggi & Sub total & \\
\hline Laki-laki & $41(38 \%)$ & $10(9 \%)$ & $5(5 \%)$ & $6(6 \%)$ & $21(20 \%)$ & $\begin{array}{c}62 \\
(58 \%)\end{array}$ \\
\hline Perempuan & $34(32 \%)$ & $8(8 \%)$ & $0(0 \%)$ & $2(2 \%)$ & $10(10 \%)$ & $\begin{array}{c}44 \\
(42 \%)\end{array}$ \\
\hline Total & $75(70 \%)$ & $18(17 \%)$ & $5(5 \%)$ & $8(8 \%)$ & $31(30 \%)$ & $\begin{array}{c}106 \\
(100 \%)\end{array}$ \\
\hline
\end{tabular}

Tabel 1 menunjukkan bahwa, mayoritas responden pada penelitian ini yaitu laki-laki sebanyak 62 orang (58\%). Sebagian besar remaja tidak mengalami masalah psikososial (70\%). Prevalensi masalah psikososial pada siswa SMA yang tinggal di asrama yaitu 31 orang (30\%) sedangkan remaja laki-laki cenderung lebih banyak mengalami masalah psikososial (20\%) dibandingkan perempuan $(10 \%)$.

Tabel 2. Perbandingan Jenis Kelamin siswa SMA dengan jenis masalah psikososial di asrama sekolah Kota Lhokseumawe tahun 2019 (n=106)

\begin{tabular}{|c|c|c|c|c|c|}
\hline \multirow{2}{*}{\begin{tabular}{c}
\multirow{2}{*}{$\begin{array}{c}\text { Jenis } \\
\text { Kelamin }\end{array}$} \\
\cline { 2 - 6 }
\end{tabular}} & \multicolumn{4}{|c|}{ Jenis Masalah Psikososial } & \multicolumn{2}{c|}{ Masalah eksternal (\%) } \\
\cline { 2 - 5 } & Masalah Emosional & Masalah Teman Sebaya & Masalah Perilaku & Hiperaktivitas & $(\%)$ \\
\hline Laki-laki & $10(9 \%)$ & $31(29 \%)$ & $16(15 \%)$ & $5(5 \%)$ & $\begin{array}{c}62 \\
(58 \%)\end{array}$ \\
\hline Perempuan & $15(14 \%)$ & $21(20 \%)$ & $4(4 \%)$ & $4(4 \%)$ & $\begin{array}{c}44 \\
(42 \%)\end{array}$ \\
\hline Total & $25(23 \%)$ & $52(49 \%)$ & $19(19 \%)$ & $9(9 \%)$ & 106 \\
$(100 \%)$
\end{tabular}


Tabel 2 menunjukkan bahwa setidaknya, setiap siswa SMA yang tinggal di asrama mengalami satu masalah psikososial yang sebagian besar dialami oleh remaja laki-laki sebanyak 62 orang (58\%). Masalah yang paling banyak dialami oleh remaja yaitu masalah teman sebaya (49\%), diikuti oleh masalah emosional (23\%), masalah perilaku (19\%), dan hiperaktivitas (9\%). Remaja laki-laki lebih banyak mengalami masalah teman sebaya dan masalah perilaku, sedangkan remaja perempuan lebih banyak mengalami masalah emosional.

\section{PEMBAHASAN}

Hasil penelitian ini menyimpulkan bahwa $30 \%$ remaja yang tinggal di asrama mengalami masalah psikososial (tabel 1). Bila dibandingkan dengan prevalensi masalah kesehatan jiwa pada remaja di Amerika Serikat (13-20\%) dan negara-negara Asia (10-20\%) (Srinath, Kandasamy \& Golhar, 2010), maka prevalensi masalah psikososial pada remaja di Lhokseumawe cukup tinggi, tetapi hasil ini masih dibawah prevalensi remaja eskimo yang mengalami masalah sosial dan emosional yang mencapai 49\% (Kleinfeld \& Bloom, 1977). Menariknya, remaja yang tinggal di asrama ternyata menunjukkan prevalensi masalah psikososial yang lebih tinggi dibandingkan dengan remaja yang tidak tinggal di asrama. Hal ini dapat disebabkan karena remaja yang tinggal di asrama harus mengikuti peraturan-peraturan dan kegiatankegiatan yang sudah ditetapkan, termasuk intensitas interaksi dengan teman sebaya yang tinggi, sehingga meningkatkan risiko masalah psikososial (Martin, Papworth, Ginns \& Liem, 2014).

Meskipun mayoritas remaja yang tinggal di asrama tidak mengalami masalah psikososial (70\%), tetapi bila ditelaah per dimensi, maka setiap siswa masingmasing mengalami satu masalah psikososial. Hal ini dapat terjadi, karena kuesioner SDQ dapat mengevaluasi dimensi masalah psikososial secara terpisah, sehingga siswa yang menjadi responden pada penelitian ini dapat dikaji secara spesifik risiko masalah jiwa yang 
dialaminya (Goodman, 1997). Selain itu, penelitian ini juga menunjukkan sebagian besar remaja laki-laki (58\%) cenderung mengalami lebih banyak masalah psikososial dibandingkan remaja perempuan (42\%) dan dari jumlah tersebut, sebagian besar remaja perempuan menunjukkan masalah emosional $(14 \%)$.

Hasil ini sejalan dengan penelitian yang dilakukan oleh Saputra, Yunibhand \& Sukratul (2017) yang menyatakan bahwa anak perempuan memang cenderung memiliki masalah emosional dimana mereka cenderung bersikap pasif dan menyembunyikan perasaannya dibandingkan dengan anak laki-laki. Tetapi penelitian Chabra, Chaves \& Harris (1999) menemukan bahwa sebagian besar anak laki-laki dirawat di Rumah Sakit California karena masalah mental emosional. Masalah emosional pada remaja tidak dapat disepelekan, karena bila tidak dideteksi secara dini dan mendapatkan penanganan awal yang tepat, maka remaja tersebut berisiko mengalami depresi karena depresi pada remaja dapat meningkatkan risiko bunuh diri (Consoli dkk, 2013; Fathonah, Herawaty \& Fitria, 2017). Penelitian ini juga menyimpulkan bahwa, remaja lakilaki yang tinggal di asrama lebih banyak memiliki masalah teman sebaya (29\%) dan masalah perilaku (15\%). Hasil ini sesuai dengan penelitian Wiguna dkk (2010), mereka menemukan bahwa sebanyak $54,81 \%$ anak dan remaja yang berkunjung ke poliklinik jiwa anak dan remaja di Rumah Sakit Cipto Mangunkusumo menunjukkan masalah teman sebaya. Masalah teman sebaya pada anak dan remaja dapat berupa tindakan bullying, mengintimidasi, mengancam, mengejek, dan menganiaya teman sepermainannya. Sedangkan masalah perilaku pada remaja memiliki implikasi yang lebih mengkhawatirkan, karena ketika remaja beranjak dewasa, mereka cenderung akan terlibat dalam tindakan kriminal dan melanggar hukum, seperti tindakan pencurian, pemerkosaan, pemerasaan, pembunuhan, dan penyalahgunaan serta pengedaran Narkoba (Aebi dkk, 2014). 


\section{KESIMPULAN}

Berdasarkan hasil penelitian ini dapat disimpulkan bahwa 30\% remaja yang melanjutkan pendidikan pada sekolah berasrama berisiko mengalami masalah psikososial. Remaja perempuan cenderung mengalami masalah emosional, sedangkan remaja laki-laki cenderung mengalami masalah teman sebaya dan masalah perilaku.

\section{UCAPAN TERIMA KASIH}

1. Terima kasih kepada pihak Pusat Pelayanan Terpadu Pemberdayaan Perempuan dan Anak (P2TP2A) kota Lhokseumawe yang telah menfasilitasi pelaksanaan kegiatan penyuluhan dan penelitian masalah psikososial pada remaja yang tinggal di asrama.

2. Terima kasih kepada kepala sekolah, dewan guru, dan siswa salah satu SMA swasta di Kota Lhokseumawe yang telah berpartisipasi dan membantu selama proses pengumpulan data dilaksanakan.

\section{DAFTAR PUSTAKA}

Aebi, M., Giger, J., Plattner, B., Metzke, C.W., Steinhausen, H.S. (2014). Problem coping skills, psychological adversities and mental health problems in children and adolescents as predictors of criminal outcomes in young adulthood. Eur. Child Adolesc. Psychiatry 23, 283293.

Badan Pusat Statistik. (2019). Statistik Pemuda Indonesia 2019. Jakarta: BPS

Chabra, A., Chavez, G.F., Harris, E.S. (1999). Mental illness in elementary-school-aged children. West. J. Med. 170 (1), 28-34. Diunduh dari http://www.ncbi.nlm.nih.gov/ pmc/articles/PMC1305432/)

Consoli, A., Peyre, H., Speranza, M. et al. (2013). Suicidal behaviors in depressed adolescents: role of perceived relationships in the family. Child Adolesc Psychiatry Ment Health 7, 8. https://doi.org/10.1186/17532000-7-8 
Fathonah, D. W., Hernawaty, T \& Fitria, N. (2017). Respon psikososial siswa asrama

di Bina Siswa SMA Plus Cisarua Jawa Barat. Jurnal Pendidikan Keperawatan Indonesia. Volume 3(1):6977.

Galaif, E. R., Sussman, S., Newcomb, M. D., \& Locke, T. F. (2007). Suicidality, depression, and alcohol use among adolescents: a review of empirical findings. International journal of adolescent medicine and health, 19(1), 27-35. https://doi.org/10.1515/ijamh. 2007.19.1.27

Goodman, R. (1997). The strengths and difficulties questionnaire: a research note. J. Child Psychol. Psychiatry 38, 581586.

Goodman, R. Indonesian. (2014). Youth in mind. Diunduh dari http://www.sdqinfo.com/py/s dqinfo/b3.py?language $=$ Indo nesian.

Hallfors, Denise \& Waller, Martha \& Ford, Carol \& Halpern,
Carolyn \& Brodish, Paul \& Iritani, Bonita. (2004). Adolescent depression and suicide risk: Association with sex and drug behavior. American Journal of Preventive Medicine. 27. 224-31.

10.1016/j.amepre.2004.06.00 1.

Keliat, Budi Anna dan Akemat. (2015). Keperawatan Jiwa: Terapi Aktifitas Kelompok (edisi 2). Jakarta: EGC.

Keliat dkk. (2020). Asuhan Keperawatan Jiwa. Jakarta: EGC.

Kleinfeld J, Bloom J. (1977). Boarding schools: effects on the mental health of Eskimo adolescents. Am J Psychiatry. Volume 134(4):411-417. doi:10.1176/ajp.134.4.411

Mander, D.J. \& Lester, L. (2017). A Longitudinal Study Into Indicators of Mental Health, Strengths and Difficulties Reported by Boarding Students as They Transition From Primary School to Secondary Boarding Schools 
in Perth, Western Australia. Journal of Psychologists and Counsellors in Schools 139. Volume 27 (2) pp. 139-152. doi 10.1017/jgc.2017.1

Martin, A.J., Papworth, B., Ginns, P. \& Liem, G.A.D. (2014). Boarding school, motivation and engagement, and psychological well-being: $A$ large-scale investigation. American Educational Research Journal, 51, 10071049.

Oktaviana, M \& Wimbarti, S. (2014). Validasi klinik Strenghts and Difficulties Questionnaire sebagai instrument skrining gangguan tingkah laku. Jurnal Psikologi Universitas Gajah Mada. Diunduh dari http://jurnal.psikologi.ugm.ac .id/index.php/fpsi/article/view $/ 192$.

Saputra, F., Yunibhand, Y, \& Sukratul, S. (2017). Relationship between personal, maternal, and familial factors with mental health problems in school- aged children in Aceh province, Indonesia. Asian Journal of Psychiatry 25, 207-212.

http://dx.doi.org/10.1016/j.ajp .2016 .10 .025

Sukma, R. N. (2016). Dari Skrining 1.300 Siswa SMA di Jaksel, 30 Persen Berpotensi Depresi. Diunduh dari https://health.detik.com/berita -detikhealth/d-3317807/dariskrining-1300-siswa-sma-dijaksel-30-persen-berpotensidepresi

Srinath, S., Kandasamy, P., Golhar, T.S. (2010). Epidemiology of child and adolescent mental health disorders in Asia. Curr. Opin. Psychiatry 23 (4), 330-336. Diunduh dari http://www.ncbi.nlm.nih.gov/ pubmed/ 16106093).

Verhulst, F. C \& Ende, J. V. (2006). Assessment scales in child and adolescent psychiatry. London: Informa UK Ltd. Wiguna, T., Manengkei, P.S.K., Pamela, C., Rheza, A.M., Hapsari, W.A., 2010. Masalah emosi dan perilaku 
pada anak dan remaja di poliklinik jiwa anak dan remaja RSUPN $\mathrm{dr}$ Ciptomangunkusumo (RSCM). Jakarta. Sari Pediatr. 12, 270-277. 
